\title{
Helicobacter pylori cagA and vacA genotypes in Cuban and Venezuelan populations
}

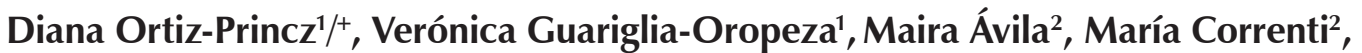 \\ Marianella Perrone $^{3}$, Beatriz Gutierrez ${ }^{4}$, Javier Torres ${ }^{5}$, Francis Megraud ${ }^{6}$, María Eugenia Cavazza ${ }^{1}$
}

'Laboratorio de Microbiologia Molecular, Instituto de Biomedicina, ${ }^{2}$ Laboratorio de Genética Molecular, Instituto de Oncología y Hematología, Ministerio del Poder Popular para la Salud, Universidad Central de Venezuela, Esquina San Nicolás a Providencia Parroquia San José, Apartado Postal 4043, 1010A Caracas, Venezuela ${ }^{3}$ Facultad de Odontologia Universidad Central de Venezuela, Caracas, Venezuela ${ }^{4}$ United Nations Framework Convention on Climate Change de La Habana, La Habana, Cuba ${ }^{5}$ Unidad de Investigación Médica en Enfermedades Infecciosas y Parasitarias, Instituto Mexicano del Seguro Social, México City, México ${ }^{6} I N S E R M ~ U 853$, Bordeaux, France

The aim of this study was to determine the presence of Helicobacter pylori cytotoxin-associated gene (cagA)/ vacuolating cytotoxin gene ( $\mathrm{vac} A$ ) among patients with chronic gastritis in Cuba and Venezuela. Gastric antrum biopsies were taken for culture, DNA extraction and PCR analysis. Amplification of vacA and $\operatorname{cag} A$ segments was performed using two regions of $\mathrm{cag} A$ : $349 \mathrm{bp}$ were amplified with the F1/B1 primers and the remaining $335 \mathrm{bp}$ were amplified with the B7629/B7628 primers. The VA1-F/VA1-R set of primers was used to amplify the 259-bp (s1) or 286$b p(s 2)$ product and the VAG-R/VAG-F set of primers was used to amplify the 567-bp (m1) or 642-bp (m2) regions of vac $A$. cag $A$ was detected in $87 \%$ of the antral samples from Cuban patients and $80.3 \%$ of those from Venezuelan patients. All possible combinations of vac $A$ regions were found, with the exception of $s 2 / m 1$. The predominant combination found in both countries was $s 1 / \mathrm{ml}$. The percentage of cag $A^{+}$strains was increased by the use of a second set of primers and a greater number of strains was amplified with the B7629/B7628 primers in the Cuban patients $(p=0.0001)$. There was no significant difference between the presence of the allelic variants of $\operatorname{vac} A$ and $\operatorname{cag} A$ in both populations. The predominant genotype was $\mathrm{cag} A+/$ s $1 m 1$ in both countries. The results support the necessary investigation of isolates circulating among the human population in each region.

Key words: Helicobacter pylori - cagA - vacA - chronic gastritis

Helicobacter pylori is a microaerophilic bacterium that has the ability to establish an infection in human stomachs that can last for years or even decades, despite immune and inflammatory responses and the normal turnover of the gastric epithelium in which it resides (Kersulyte et al. 2000). Infection with this microorganism is not only the major cause of chronic active gastritis and most peptic ulcer diseases, but it is also associated with gastric cancers (Blaser \& Berg 2001). Among the different genetic determinants involved in $H$. pylori virulence are the cytotoxin-associated gene ( $\operatorname{cagA})$ and the vacuolating cytotoxin gene ( $v a c \mathrm{~A})$. Various studies have demonstrated the importance of the presence of these genes in the strain affecting a patient and in the development of gastric disease (Faundez et al. 2002, Chen et al. 2005) vacA encodes a vacuolating toxin that is released by $H$. pylori and that injures epithelial cells via its poreforming ability. vacA is present in all H. pylori strains, but

Financial support: FONACIT (IB-G- 2005000371), Project Misión Ciencia (G-2007001425)

+Corresponding author:dprincz@gmail.com

DO-P and VG-O contributed equally to this work.

Received 16 November 2009

Accepted 25 February 2010 it is not similarly expressed in all strains. It includes two variable regions, denoted $\mathrm{s}$ and $\mathrm{M}$. The $\mathrm{s}$ region (encoding the signal peptide) is located at the 5 ' end of the gene and exists as an s1 or s2 allele. Within type s1, two subtypes (sla and slb) can be distinguished. The $\mathrm{m}$ region (middle region) occurs as an $\mathrm{m} 1$ or $\mathrm{m} 2$ allele. All possible combinations of these vacA regions have been identified, with the exception of $\mathrm{s} 2 / \mathrm{m} 1$. The mosaic combination of the $\mathrm{s}$ and $\mathrm{m}$ region allelic types correlates with the production of the cytotoxin and is thereby associated with the virulence of the strain (Atherton et al. 1995).

The cytotoxin-associated protein is a high molecular mass immunodominant protein encoded by cagA that is part of the cag pathogenicity island (Tummuru et al. 1993) and is also a disease-associated virulence factor. Several reports have evidenced geographical differences in the prevalence of vacA alleles and cagA status among H. pylori isolates (Kersulyte et al. 2000, Catalano et al. 2001, Valmaseda-Perez et al. 2001); however, there is limited information about $H$. pylori infection in the countries of the Caribbean basin. The aim of this study was to determine the frequency of different $H$. pylori $c a g \mathrm{~A} / v a c \mathrm{~A}$ genotypes among patients with chronic gastritis in Cuba and Venezuela.

\section{PATIENTS, MATERIALS AND METHODS}

Subjects - Sixty-one patients from Venezuela, aged between $25-76$ years (average $49 \pm 14$ years; 34 patients 
from the José Maria Vargas Hospital in Caracas, 17 from the Gastric Cancer Control Center in San Cristobal, Táchira and 10 from the University Hospital in Caracas) and 71 patients, aged between 23-75 years (average $50 \pm$ 12 years), all from the Institute of Gastroenterology in La Havana, Cuba, all of which were referred for upper gastrointestinal endoscopy after presenting dyspeptic symptoms and participated in this study. Both groups were balanced regarding sex and socioeconomic conditions, with Venezuelan patients being scored socioeconomically according to the method of Graffar modified for Venezuela (Méndez 1986).

Each patient underwent upper gastroendoscopy for both endoscopic observation and biopsy collection for histological study, culture and PCR analysis. Endoscopic observation and histological confirmation were used to determine patient pathologies according to the updated Sydney system (Dixon et al. 1996) and patients with chronic active gastritis were selected for this study. All patients with chronic active gastritis were positive for H. pylori. In biopsies from Venezuelan patients, positivity was confirmed by the rapid urease test, histological study and PCR for glmM (Kamali-Sarvestani 2006). In Cuban patients, strains were isolated from gastric biopsies using the conditions described below.

Informed consent was obtained from all study subjects. The procedures used were in accordance with ethical standards and the protocol was approved by the ethical committee.

Sample collection - Two antral biopsy specimens were taken from each dyspeptic patient: one for culture and one for PCR.

Culture of $H$. pylori from biopsies - Gastric biopsies were collected from the transport medium and cells were plated onto blood agar and chocolate agar plates. Plates were incubated for seven days at $37^{\circ} \mathrm{C}$ in a microaerobic atmosphere $\left(7 \% \mathrm{CO}_{2}\right)$. Isolates of $\mathrm{H}$. pylori were identified by Gram staining and catalase, oxidase and urease testing.

DNA extraction - In Venezuela, DNA was obtained from the biopsies of the 61 patients using a proteinase $\mathrm{K}$ protocol. Biopsies were incubated overnight at $50^{\circ} \mathrm{C}$ in lysis buffer (10 mM Tris- $\mathrm{HCl}, 0.1 \%$ sacarosine, $\mathrm{pH} 8.0$ ). Samples were then treated with an isoamilic chloroformphenol mixture. DNA was precipitated with ammonium acetate and $70 \%$ ethanol and then resuspended in $50 \mu \mathrm{L}$ of DNAse-free water.

In Cuba, DNA was extracted from the strains isolated from the 71 patients by harvesting cells from plates and suspending them in a sterile saline solution. Following centrifugation, the pellets were resuspended in STE buffer $(0.1$ $\mathrm{M} \mathrm{NaCl}, 1 \mathrm{mM}$ EDTA, $10 \mathrm{mM}$ Tris-HCl) and lysozyme (50 $\mathrm{mg} / \mathrm{mL}$ on $50 \%$ glycerol) and treated with $10 \%$ SDS

TABLE I

Primers used for cytotoxin-associated gene (cagA) and the vacuolating cytotoxin gene (vacA) typing of Helicobacter pylori

\begin{tabular}{|c|c|c|c|}
\hline Allele & Primer designation & Product size & Reference \\
\hline $\operatorname{cagA}$ & B7629/B7628 & $335 \mathrm{bp}$ & Gonzalez-Valencia et al. (2000) \\
\hline $\operatorname{cagA}$ & $\mathrm{F} 1 / \mathrm{B} 1$ & $349 \mathrm{bp}$ & Tummuru et al. (1993) \\
\hline vacA & & $567 \mathrm{bp}(\mathrm{m} 1)$ & \\
\hline $\mathrm{m} 1 / \mathrm{m} 2$ & VAG-R/VAG-F & $642 \mathrm{bp}(\mathrm{m} 2)$ & Atherton et al. (1995) \\
\hline$v a c \mathrm{~A}$ & & $259 \mathrm{bp}(\mathrm{s} 1)$ & \\
\hline $\mathrm{s} 1 / \mathrm{s} 2$ & VA1-F/VA1-R & $286 \mathrm{bp}(\mathrm{s} 2)$ & Atherton et al. (1995) \\
\hline
\end{tabular}

TABLE II

Prevalence of cytotoxin-associated gene ( cagA) and allelic variants of vacuolating cytotoxin gene (vacA) in Helicobacter pylori strains isolated from Cuban and Venezuelan patients

\begin{tabular}{|c|c|c|c|c|c|c|}
\hline & \multicolumn{2}{|c|}{$\operatorname{cagA}$} & \multicolumn{4}{|c|}{$v a c \mathrm{~A}$} \\
\hline & 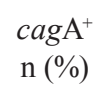 & $\begin{array}{l}\operatorname{cagA} \\
\mathrm{n}(\%)\end{array}$ & $\begin{array}{c}\text { s1 } \\
\text { n (\%) }\end{array}$ & $\begin{array}{c}\text { s2 } \\
\text { n (\%) }\end{array}$ & $\begin{array}{c}\mathrm{m} 1 \\
\mathrm{n}(\%)\end{array}$ & $\begin{array}{c}\mathrm{m} 2 \\
\mathrm{n}(\%)\end{array}$ \\
\hline $\mathrm{Cuba}^{a}$ & $62(87)$ & $9(13)$ & $44(70)$ & $19(30)$ & $31(49)$ & $32(51)$ \\
\hline Venezuela $^{b}$ & $49(80)$ & $12(20)$ & $47(77)$ & $14(23)$ & $38(62)$ & $23(38)$ \\
\hline
\end{tabular}

$a$ : isolates from Cuban patients $(\mathrm{n}=71)$ without co-infection $(\mathrm{n}=63) ; b$ : isolates from Venezuelan patients $(\mathrm{n}=61)$. 
and proteinase K $(1000 \mu \mathrm{g} / \mathrm{mL})$. Samples were treated with an isoamilic chloroform-phenol mixture and DNA was precipitated with ammonium acetate and 70\% ethanol. DNA was suspended in $50 \mu \mathrm{L}$ of DNAse-free water.

PCR amplification of the 349-bp region of cagA (Table I) - A 349-bp region of cagA was amplified by PCR using primers F1/B1 (Tummuru et al. 1993). Aliquots were taken from each DNA suspension of every patient and processed as follows: 35 cycles of $94^{\circ} \mathrm{C}$ for $1 \mathrm{~min}$, $55^{\circ} \mathrm{C}$ for $1 \mathrm{~min}$ and $72^{\circ} \mathrm{C}$ for $2 \mathrm{~min}$ and a final extension at $72^{\circ} \mathrm{C}$ for $6 \mathrm{~min}$.

PCR amplification of the 335-bp region of cagA A 335-bp region of cagA was amplified by PCR using primers B7628/B7629 (Gonzalez-Valencia et al. 2000). Aliquots of each DNA suspension from every patient were obtained and processed as follows: 35 cycles of $94^{\circ} \mathrm{C}$ for $1 \mathrm{~min}, 55^{\circ} \mathrm{C}$ for $1 \mathrm{~min}$ and $72^{\circ} \mathrm{C}$ for $2 \mathrm{~min}$ and a final extension at $72^{\circ} \mathrm{C}$ for $6 \mathrm{~min}$.

PCR amplification of the $\mathrm{s} 1 / \mathrm{s} 2$ and $\mathrm{m} 1 / \mathrm{m} 2$ alleles of $v a c A$ - We used the VA1-F/VA1-R (Atherton et al. 1995) set of primers to amplify the 259-bp (s1) or the 286-bp (s2) region of the conserved portion of vacA. The second set of primers, VAG-R/VAG-F (Atherton et al. 1995) was used to amplify the 567-bp (m1) or the 642-bp (m2) region of the conserved portion of vacA. Aliquots were taken from each DNA suspension of every patient and processed as follows: 35 cycles of $94^{\circ} \mathrm{C}$ for $1 \mathrm{~min}, 52^{\circ} \mathrm{C}$ for $1 \mathrm{~min}$ and $72^{\circ} \mathrm{C}$ for $1 \mathrm{~min}$ and a final extension at $72^{\circ} \mathrm{C}$ for $6 \mathrm{~min}$ for $\mathrm{s} 1 / \mathrm{s} 2$; and 35 cycles of $94^{\circ} \mathrm{C}$ for $30 \mathrm{sec}$, $56^{\circ} \mathrm{C}$ for $1 \mathrm{~min}$ and $72^{\circ} \mathrm{C}$ for $1.5 \mathrm{~min}$ and a final extension at $72^{\circ} \mathrm{C}$ for $5 \mathrm{~min}$ for $\mathrm{m} 1 / \mathrm{m} 2$. All of the PCR products were visualized by electrophoresis in a $1 \%$ agarose gel stained with ethidium bromide. Electrophoresis was conducted at $80 \mathrm{~V}$ for approximately $2 \mathrm{~h}$ and gels were examined under UV light.

Statistical analysis - All statistical analyses were performed using GraphPad InStat. A chi-square test was used to compare the frequencies. A $p$ value $<0.05$ was considered as significant.

\section{RESULTS}

In this study, we amplified different alleles of vacA and cagA by PCR. A total of 61 strains from Venezuelan patients and 71 strains from Cuban patients were analyzed. Out of the 71 patients from Cuba, we found that eight had a coinfection with at least two different $H$. pylori isolates, because we detected the presence of both $\mathrm{m} 1$ and $\mathrm{m} 2$ alleles. Thus, the number of isolates analyzed for the prevalence of cagA and allelic variants of vacA was reduced to 63 .

To type the $H$. pylori strains isolated from the patients examined in this study, we amplified by PCR different alleles of the genes of the two major virulence factors of this bacteria, $\operatorname{cagA}$ and $v a c \mathrm{~A}$. The amplification results are shown in Table II. cagA was detected in 62 of the 71 Cuban patients (87\%) and in 49 of the 61 Venezuelan patients $(80 \%)$, with no significant differences detected between the two countries. Four different vacA alleles were amplified from all isolates. We found all possible combinations of these vacA regions except $\mathrm{s} 2 / \mathrm{m} 1$.The most prevalent combination of $v a c A$ alleles found in both countries was s1m1, with no significant difference found between the two countries.

The results of the prevalence of cagA in relation to the different allelic combinations of vacA are represented in Table III. We observed that the predominant genotype was $\operatorname{cagA}^{+} / \mathrm{s} 1 \mathrm{~m} 1$ in both countries, with no significant difference found (Table III).

As previously mentioned, cagA was found in isolates from 62 of the 71 Cuban patients (87\%) and 49 of the 61 Venezuelan patients, with no significant difference found between the two countries. However, we found a significant difference in the amplification efficiency of the two primers, as the 335-bp primers more effectively amplified this region of cagA in $H$. pylori isolates from Cuban patients.

The 349-bp region of cagA gene was amplified from 34 of the 61 Venezuelan patients $(56 \%)$ and from 20 of the 71 Cuban patients $(28 \%)$.

We used a different set of primers, which amplify a 335-bp region of the same gene, to confirm the detection of cagA. In both countries, the percentage of detected $\operatorname{cagA}^{+}$strains was increased by the use of these primers, to $80 \%$ of the Venezuelan strains and $87 \%$ of the Cuban strains, with no significant difference found between the two countries. However, a significantly greater number of strains was amplified with the 335-bp primes from the Cuban patients $(\mathrm{p}=0.0001)$ (Table IV).

Therefore, the distribution of $\operatorname{cagA}^{+} / \mathrm{s} 1 \mathrm{ml}$ strains, relative to the different sets of primers, also showed a significant difference in both countries. The $\operatorname{cagA} 335^{+} /$ slm1 strains were more frequent in Cuban patients than in Venezuelan patients and consequently the $\operatorname{cagA} 349^{+}$/ slm1 strains were more frequent in the Venezuelan patients than in the Cuban patients $(\mathrm{p}=0.0001)$ (Figs 1,2$)$.

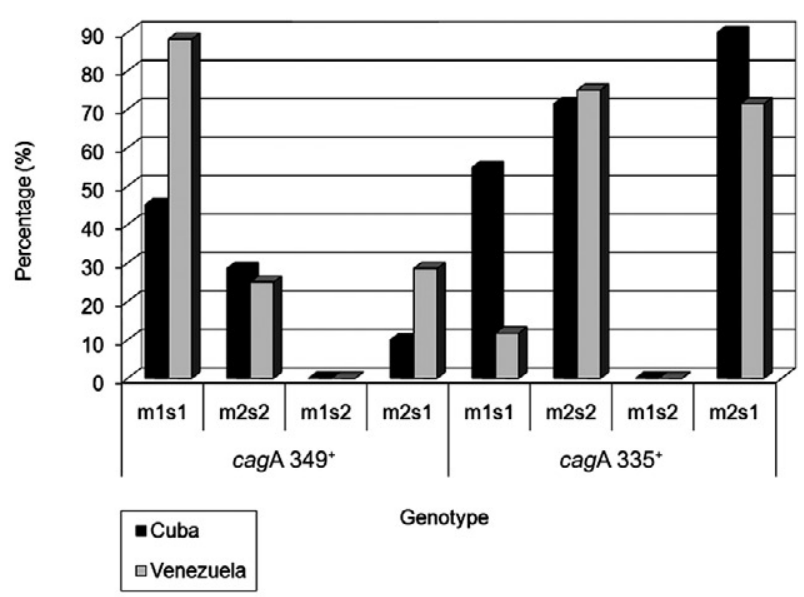

Fig. 1: genotype frequency of cytotoxin-associated gene (cagA) positive Helicobacter pylori strains isolated from patients in Cuba and Venezuela. 


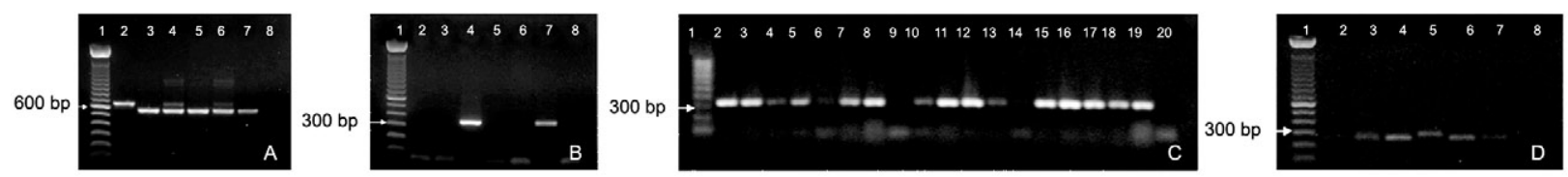

Fig. 2: electrophoresis photographs of all amplified genes. A: PCR amplification of $\mathrm{m} 1 / \mathrm{m} 2$ region of the vacuolating cytotoxin gene (vacA) gene (Lane 1: ladder; 2-6: DNA samples from strains; 7: positive control; 8: negative control); B: PCR amplification of the $349 \mathrm{bp}$ region of the cytotoxin-associated gene (cagA) gene (Lane 1: ladder; 2-6: DNA samples from strains; 7: positive control; 8: negative control); C: PCR amplification of the 335bp region of the cagA gene (Lane 1: ladder; 2-18: DNA samples from strains; 19: positive control; 20: negative control); D: PCR amplification of s1/s2 region of the vacA gene (Lane 1: ladder; 2-6: DNA samples from strains; 7: positive control; 8: negative control).

\section{TABLE III}

Prevalence of cytotoxin-associated gene ( $\operatorname{cagA})$ related to the different allelic combinations of vacuolating cytotoxin gene (vacA) and to the country of origin

\begin{tabular}{|c|c|c|c|c|c|c|c|c|}
\hline & \multicolumn{4}{|c|}{$\operatorname{cag} \mathrm{A}^{+}$} & \multicolumn{4}{|c|}{$\operatorname{cag\mathrm {A}^{-}}$} \\
\hline & $\begin{array}{l}\mathrm{s} 1 \mathrm{~m} 1 \\
\mathrm{n}(\%)\end{array}$ & $\begin{array}{l}\mathrm{s} 2 \mathrm{~m} 2 \\
\mathrm{n}(\%)\end{array}$ & $\begin{array}{l}\mathrm{s} 1 \mathrm{~m} 2 \\
\mathrm{n}(\%)\end{array}$ & $\begin{array}{l}\mathrm{s} 2 \mathrm{~m} 1 \\
\mathrm{n}(\%)\end{array}$ & $\begin{array}{l}\mathrm{s} 1 \mathrm{~m} 1 \\
\mathrm{n}(\%)\end{array}$ & $\begin{array}{l}\mathrm{s} 2 \mathrm{~m} 2 \\
\mathrm{n}(\%)\end{array}$ & $\begin{array}{l}\mathrm{s} 1 \mathrm{~m} 2 \\
\mathrm{n}(\%)\end{array}$ & $\begin{array}{l}\mathrm{s} 2 \mathrm{~m} 1 \\
\mathrm{n}(\%)\end{array}$ \\
\hline Cuba & 31 (49) & $14(22)$ & $10(16)$ & $0(0)$ & $0(0)$ & $5(8)$ & $3(5)$ & $0(0)$ \\
\hline Venezuela & $35(57)$ & $8(13)$ & $7(11)$ & $0(0)$ & $3(5)$ & $6(10)$ & $2(3)$ & $0(0)$ \\
\hline
\end{tabular}

isolates from Cuban patients without co-infection $(n=63)$ and isolates from Venezuelan patients $(n=61)$.

TABLE IV

Frequency of positivity according to the DNA fragment of cytotoxin-associated gene (cagA) amplified in Cuba and Venezuela

\begin{tabular}{|c|c|c|c|}
\hline & $\begin{array}{c}\text { bp region } 335^{+} \\
\mathrm{n}(\%)\end{array}$ & $\begin{array}{c}\text { bp region } 349^{+} \\
\text {n }(\%)\end{array}$ & $\begin{array}{c}\text { Total } \\
\mathrm{n}\end{array}$ \\
\hline Cuba & $42(59)$ & $20(28)$ & 62 \\
\hline Venezuela & $15(25)$ & $34(56)$ & 49 \\
\hline
\end{tabular}

\section{DISCUSSION}

Infection with H. pylori has been related to serious gastroduodenal diseases, such as gastric and duodenal ulcers and gastric cancers. This infection is a worldwide health problem and thus it is important to diagnose the presence of this bacterium and its genotype accurately, in the patient. There is increasing evidence that the presence of $H$. pylori genes and their different genotypic combinations in the strain colonizing a patient affects the development of gastric disease.

The predominant combination of vacA alleles in both countries was $\mathrm{s} 1 / \mathrm{m} 1$ and the prevalence was similar in both countries. The mosaic combination of $\mathrm{s}$ and $\mathrm{m}$ region allelic types correlates with the production of the cytotoxin and is thereby associated with the virulence of the strain; the fact that the majority of the strains found in Cuban and Venezuelan patients are $\mathrm{s} 1 / \mathrm{m} 1$, the most virulent type, is of importance to the regional health systems of both countries. These results are in accordance with several other studies (De Gusmão et al. 2000,
Figueiredo et al. 2001, Chen et al. 2005, Martins et al. 2005, Garcia et al. 2006).

We found a significant difference in amplification efficiency between the two primers used, with the 335bp primers being more effective at amplifying this region of cagA in $H$. pylori isolates from Cuban patients. There have been indications of sequence variability in cagA in isolates of different geographic origins (Pan et al. 1997, van Doorn et al. 1998) and this may lead to an underestimation of the true prevalence of cagA-positive H. pylori strains.

Further studies carried out in our lab, where we have amplified other regions of cagA, suggest that the percentage of cagA-positive strains, as measured using only one set of primers, is usually underestimated.

The results of this study provide important information in the epidemiological study of the frequency of $\operatorname{cag} A$ in Caribbean populations. When we simultaneously evaluated the presence of cagA and vacA alleles, we found that the predominant genotype in both coun- 
tries was $\operatorname{cagA}^{+} / \mathrm{s} 1 \mathrm{~m} 1$. This finding is in accordance with other studies performed in Latin American populations. Faundez et al. (2002) found that $\operatorname{cagA}^{+} / \mathrm{s} 1 \mathrm{~m} 1$ strains were the most common in Chilean patients and Morales-Espinosa et al. (1999) also found that $\mathrm{cagA}^{+} / \mathrm{s} 1 \mathrm{~m} 1$ strains had a higher prevalence in Mexican patients. Additionally, Martins et al. (2005) found an association between the $\operatorname{cagA}^{+}$and vacAm1s1 genotypes in Northern Brazil and Cittelly et al. (2002) found that the $\operatorname{cagA}^{+} / \mathrm{s} 1 \mathrm{~m} 1$ phenotype was the most frequent in Colombian patients. Given the fact that the genotype $\operatorname{cag} A+/ \operatorname{sim} 1$ is highly associated with a more severe gastroduodenal disease, these data are of great importance for the regional health systems of Cuba and Venezuela.

PCR amplification of the major virulence factor genes of $H$. pylori proved to be an efficient method for genotyping the strains isolated from both countries. Even though we did not find any significant differences between the genotype distributions in both countries, we found that a significantly higher number of strains isolated from Cuban patients were amplified with the 335-bp primers. Sequencing of the entire cagA gene will be performed to complete the study and to elucidate the genetic differences that account for this preferential primer amplification. We also found that the predominant genotype in both countries was $c a g \mathrm{~A}^{+} / v a c \mathrm{~A}$ slm1. Because this is the genotype most commonly associated with more severe gastric disease, we strongly suggest that $H$. pylori infection should be considered as a public health problem in our countries and that preventive measures be taken. In addition, this study demonstrates that diversity mainly in $\operatorname{cag} A$ sequences needs to be evaluated carefully for investigation of the isolates circulating among human populations in epidemiological studies of $H$. pylori genotypes.

\section{REFERENCES}

Atherton JC, Cao P, Peek RM Jr, Tummuru MK, Blaser MJ, Cover TL 1995. Mosaicism in vacuolating cytotoxin alleles of Helicobacter pylori. Association of specific vacA types with cytotoxin production and peptic ulceration. J Biol Chem 270: 17771-17777.

Blaser MJ, Berg DE 2001. Helicobacter pylori genetic diversity and risk of human disease. $J$ Clin Invest 7: 767-773.

Catalano M, Matteo M, Barbolla RE, Jimenez Vega DE, Crespo O, Leanza AG, Toppor J, Antelo P 2001. Helicobacter pylori vacA genotypes, cagA status and ureA-B polymorphism in isolates recovered from an Argentine population. Diagn Microbiol Infect Dis 41: 205-210.

Chen XJ, Yan J, Shen YF 2005. Dominant cagA/vacA genotypes and coinfection frequency of $H$. pylori in peptic ulcer or chronic gastritis patients in Zhejiang Province and correlations among different genotypes, coinfection and severity of the diseases. Chin Med J 118: 460-467.

Cittelly DM, Huertas MG, Martínez JD, Oliveros R, Posso H, Bravo MM, Orozco O 2002. Helicobacter pylori genotypes in non atrophic gastritis are different of the found in peptic ulcer, premalignant lesions and gastric cancer in Colombia. Rev Med Chil 130: 143-151.

De Gusmão VR, Nogueira R, Mendes E, De Magalhães A, Queiroz DM, Aguiar Rocha G, Camargos Rocha AM, Ramadan Ashour AA, Teles Carvalho AS 2000. vacA genotypes in Helicobacter pylori strains isolated from children with and without duodenal ulcer in Brazil. J Clin Microbiol 38: 2853-2857.
Dixon MF, Genta RM, Yardley JH, Correa P 1996. Classification and grading of gastritis: the updated Sydney system. Am J Surg Pathol 20: 1161-1181.

Faundez G, Troncoso M, Figueroa G 2002. cagA and vacA in strains of Helicobacter pylori from ulcer and non-ulcerative dyspepsia patients. BMC Gastroenterol 2: 20.

Figueiredo C, Quint W, Nouhan N, van den Munckhof H, Herbrink P, Scherpenisse J, de Boer W, Schneeberger P, Perez-Perez G, Blaser MJ, van Doorn LJ 2001. Assessment of Helicobacter pylori vacA and cagA genotypes and host serological response. J Clin Microbiol 39: $1339-1344$.

García A, Barra R, Delgado C, Kawaguchi F, Trabal N, Montenegro S, González C 2006. Genotypying of clinical isolates of Helicobacter pylori by $c a g \mathrm{~A}, v a c \mathrm{~A}$ and $b a b \mathrm{~A} 2$ virulence associated genes. First detection of a babA2 positive strain in Chilean patients. Rev Med Chil 134: 981-988.

González-Valencia G, Atherton JC, Muñoz O, Dehesa M, la Garza AM, Torres J 2000. Helicobacter pylori vacA and cagA genotypes in Mexican adults and children. J Infect Dis 182: 1450-1454.

Kamali-Sarvestani E, Bazargani A, Masoudian M, Lankarani K, Taghavi AR, Saberifiroozi M 2006. Association of $H$ pylori cagA and $v a c A$ genotypes and IL-8 gene polymorphisms with clinical outcome of infection in Iranian patients with gastrointestinal diseases. World J Gastroenterol 28: 5205-5210.

Kersulyte D, Mukhopadhyay AK, Velapatiño B, Su W, Pan Z, Garcia C, Hernandez V, Valdez Y, Mistry RS, Gilman RH, Yuan Y, Gao H, Alarcón T, López-Brea M, Balakrish Nair G, Chowdhury A, Datta S, Shirai M, Nakazawa T, Ally R, Segal I, Wong BC, Lam SK, Olfat FO, Borén T, Engstrand L, Torres O, Schneider R, Thomas JE, Czinn S, Berg DE 2000. Differences in genotypes of Helicobacter pylori from different human populations. J Bacteriol 182: 3210-3218.

Martins LC, Corvelo TC, Demachki S, Araujo MT, Assumpção MB, Vilar SC, Freitas FB, Barbosa HP, Fecury AA, do Amaral RK, Dos Santos SE 2005. Clinical and pathological importance of vacA allele heterogeneity and cagA status in peptic ulcer disease in patients from North Brazil. Mem Inst Oswaldo Cruz 100: 875-881.

Méndez C 1986. Estratificación social y biología humana. Arch Venez Puer Ped 49: 93-104.

Morales-Espinosa R, Castillo-Rojas G, Gonzalez-Valencia G, Ponce de León S, Cravioto A, Atherton JC, López-Vidal Y 1999. Colonization of Mexican patients by multiple Helicobacter pylori strains with different vacA and cagA genotypes. J Clin Microbiol 37: 3001-3004.

Pan ZJ, van der Hulst RW, Feller M, Xiao SD, Tytgat GN, Dankert J, van der Ende A 1997. Equally high prevalences of infection with cagA-positive Helicobacter pylori in Chinese patients with peptic ulcer disease and those with chronic gastritis-associated dyspepsia. J Clin Microbiol 35: 1344-1347.

Tummuru MK, Cover TL, Blaser MJ 1993. Cloning and expression of a high-molecular-mass major antigen of Helicobacter pylori: evidence of linkage to cytotoxin production. Infect Immun 61: 1799-1809.

Valmaseda-Perez T, Gisbert JP, Pajares García JM 2001. Geographic differences and the role of $c a g A$ gene in gastroduodenal diseases associated with Helicobacter pylori infection. Rev Esp Enferm Diag 93: 471-480.

van Doorn LJ, Figueiredo C, Rossau R, Jannes G, van Asbroek M, Sousa JC, Carneiro F, Quint WG 1998. Typing of Helicobacter pylori vacA gene and detection of cagA gene by PCR and reverse hybridization. J Clin Microbiol 36: 1271-1276. Erratum J Clin Microbiol 38: 2464. 